International Journal of Linguistics, Literature and Translation (IJLLT)

ISSN: 2617-0299 (Online); ISSN: 2708-0099 (Print)

DOI: $10.32996 / \mathrm{ijllt}$

Website: https://al-kindipublisher.com/index.php/ijllt

\title{
Grotesque Literary Caricatures of Exotic Orientals in Tariq Ali's Play Iranian Nights
}

Areeba Tayyab

Department of English, The University of Central Punjab, Pakistan

Corresponding Author: Areeba Tayyab, E-mail: areebasohaail@gmail.com

\section{ARTICLE INFORMATION}

Received: September 01, 2020

Accepted: October 13, 2020

Volume: 3

Issue: 10

DOI: 10.32996/ijllt.2020.3.10.16

\section{KEYWORDS}

Exoticism, Orientalism, Marketing

Marginalized, Caricatures, Third

world Muslims

\section{ABSTRACT}

The paper analyzes grotesque literary caricature of the exotic Orientals in Tariq Ali and Howard Brenton's play Iranian Nights. The focus is to elucidate how the writer market margins by creating caricatural and exotic characters that generate laughter and comical wit for the international readership. The research has two folds i.e. on one level it will discuss the caricatural features in characters to understand the underline meaning for the use of such distorted and exaggerated art form in a modern play. On the other hand, the paper will have an investigative stance into the dramatic techniques used ancient grotesque plays to find out the significance of such a dramaturgy in the business of exoticism. The research broadens the scope as it presents an art form that depicts a grotesque caricature exoticizing the third world's other Orientals to market margins.

\section{Introduction}

A comprehensive study on Tariq Ali reveals the greatness of his work, his well-regarded figure among the international community of modern poets, and the plentitude of critical coverage on the quality and scope of work in terms of Geopolitics, History, Marxism, and Postcolonialism. A chronological analysis of the writer's life tells us that he was born on 21st October 1943. At the time of his birth, British India still suffered from colonialization. His parents both belonged to a feudal political background and were declared to be "both came from a very old, crusty, feudal family"(Frontline,2013). He followed the atheist ideals of his heritage as he mentioned that he has no secret about his atheist background. He also mentioned during the interview that none of his friends were believers (maybe a few).

Not just a writer, Ali has performed his services as a journalist and filmmaker as well. It is due to his passion for world politics that he is a well-known member of the editorial committee of the New Review and Sim Permiso. As an effective journalist and writer, he worked for prestigious international brands The Guardian, Counterpunch, and London Review books as well. His famous works include Pakistan: Military Rule or People's Power (1970), Can Pakistan Survive? The Death of a State (1991), Pirates Of The Caribbean: Axis Of Hope (2006), Conversations with Edward Said (2005), Bush in Babylon (2003), and Clash of Fundamentalisms: Crusades, Jihads, and Modernity (2002), A Banker for All Seasons (2007), The Duel (2008), The Obama Syndrome (2010) and The Extreme Centre: A Warning (2015).

Howard Brenton, the other author of the play, seems to have a very similar professional outlook. Born in Portsmouth, Hampshire, this son of a policeman was destined to go to Cambridge and have a good deal of study beforehand at St Catherine's College and Chichester High School for boys as a start. Son of Henry Brenton and Rose Lilian, he wrote several plays while his study in Cambridge. Notable works include Ladder of Fools, (1965) Christie in Love (1969) Gum and Goo, Brighton Combination (1969); RSC at the Open Space Theatre (1971) Revenge (1969) Heads, University of Bradford Drama Group (1969); Inter-Action at the Ambience-in-Exile Lunch Hour Theatre Club (1970)The Education of Skinny Spew, University of Bradford Drama Group (1969); Inter-Action at the Ambience-in-Exile Lunch Hour Theatre Club (1970) Fruit (1970) Wesley, Bradford Festival (1970).

K C AL-KINDI CENTER

$\mathbf{R}$ DOR RESEARCH AND R D DEVELOPMENT Your gateway to world-class research
Published by Al-KindiCenter for Research and Development. Copyright (c) the author(s). This is an open access article under CC BY license (https://creativecommons.org/licenses/by/4.0/) 
Since the depiction of characterization and perception of the third world religion is fundamental to a comprehensive understanding of the play Iranian Nights, therefore it becomes essential to introduce the major concept of grotesque literary caricatures to evaluate if these ideas lend themselves to an authentic analysis of exaggerated exoticized oriental characters.

The Grotesque is a comical and witty representation that can at times be distorted and ugly as well. Its unification with the word caricature makes it more hyperbolic in the sense that the characters are exaggerated and twistedly portrayed that the essence reminded on the mind of the reader is that of a burlesque or slapstick work. The word Grotesque is Latin by its origin, Grotesque which means a cave.

Grotesque was an extravagant roman style of artistic works but later in 16 centuries onwards, the art shifted to exaggeration and distorted images both in visual art and literature. Caricature on other hand means loaded representation and according to visual arts research, it is declared to be an exaggerated depiction of a real character in a fictional manner. A caricature is usually used in visual arts as a technique to make a comical and satiric cartoon to generate ridicule and its literature it serves the same. This paper uses all these three terms to justify the intensity of satire, ridicule, and exaggeration in portraying an exotic orient image to the international audience.

The Caricatures in Iranian Nights are physical appearances, distorted images, and morally decayed stereotypical exaggerated image of the Muslims who are drunkard, useless creatures by the lens of the west. Ali and Brenton may be considering some of the facts of the caricatures while writing as the art was considered to a popular institution in Roman times. The Grand Mimus was supported by the imperial court and it aimed to make people laugh by language, gestures, and motions of the body. In the play, the characters danced and snugged, repeated Jokes, and told stories. They also recited and acted farces and scandalous anecdotes which are called mimicry now.

In his book The History of Grotesque in Literature and Art, Thomas Wright (2000) mentions that this continued with Joculator or Jougleur in which there was a figure of the poet himself to sing and recite. Later, it became songs of satire with the idea of personal vituperation. The female character danced with little clothes on their body and made strange faces to generate laughter. Tamed Animals were carried by the actors to perform as well. From Jogulers the art shifted to the Minstrels who use to perform at a wealthy imperial mansion to enlighten their dull lives with humor. The French Fabula or Fabella serve the same function as that of grotesque caricatures. In these plays the center of ridicule where the aristocratic elite, domestic lives, middle class, and women. The clergy and the preachers were also part and parcel of the ridicule sermons of that time. Religion was a tool for mocking the masses because of the moral degradation prevailing in society. Not just the French, Anglo-Saxons, and English men but East are also responsible for generating this art, as the Jouglers had brought at the times of the crusades. There is a great possibility that the stories of the jogulers may be driven from the Eastern setup and the storylines of some of the performances also tell the same. The trend of mocking and satire was also evident in Eastern performances at that time.

The term Exotic or Exoticism also demands elucidation before the application of the grotesque caricature be made on the characters in Iranian Nights. Huggan (2014) in his book " Post-Colonial Exotic: Marketing the Margins define the exotic as:

the exotic is not, as is often supposed, an inherent quality to be found 'in certain people, distinctive objects, or specific places; exoticism describes, rather, a particular mode of aesthetic perception - one which renders people, objects, and places strange even as it domesticates them...Exoticism, in this context, might be described as a kind of semiotic circuit that oscillates between the opposite poles of strangeness and familiarity. (p.13)

The objects are exoticized to create familiarity and strangeness which again points out the grotesque caricatures. The places and the people are represented as subordinate and are used to channel a network to market publications that can make money. The Grotesque caricatures, then become a means to demonstrate the exotic perception of the writer to the developing countries, and in terms of Iranian Nights, it possibly depicts the third world Muslim generation.

The research hence considers the following research questions:

a. Why does Tariq Ali and Brenton use the art of caricature presenting farcical and buffoonish characters in Iranian Nights?

b. Why such an image of third world Muslims is depicted as a sexually perverted human being? 
c. By forming such characters, are the writers trying to market the margins?

d. Why seemingly all the characters are depicted weak and lack an intellectual or human trait?

Viewing this from an oriental perspective, Said has pointed out the reality of media and publishing press that have promoted literature with one-sided agenda. Ali and Brenton cannot be declared as one-sided superficial money-making machines and art sellers but their depiction of the grotesque caricatures can be seen as an exotic image of the orient because it entertains a certain western perception of Islam in general and one-sided sexually perverted less intellectual Muslim characters in particular.

\section{Literature Review}

The literature review will briefly discuss the mainstream critical debate going on Ali and Brenton's Play Iranian Nights to identify the research gap which will justify the undertaking of this research project. The chapter will also discuss Ali and Brenton as a dramatist who aimed at satirizing a controversial topic to exoticize the preconceived image of the orient nations. The purpose is to elucidate how Ali and Brenton by using grotesque caricature in their play depict an exotic image of the orient dramatically, thematically as well as stylistically. In Preface to his book, The Post-Colonial Exotic: Marketing at Margins, Huggan (2014) explains:

When creative writers like Salman Rushdie are seen, despite their cosmopolitan background, as representatives of Third World countries...academic concepts like postcolonialism are turned, despite their historicist pretensions, into watchwords for the fashionable study of cultural otherness-all of these are instances of the postcolonial exotic, of the global commodification of cultural difference. (p.IV)

Salman Rushdie as a representative of the third world countries follows the golden rule of exoticism in his work and the writer Ali and Brenton likewise while writing a defense may seem to be a part of a "thinly veiled agenda" by Rushdie himself. The history for the writer then becomes a study of otherness, adding the element of mystery to it. The Cosmopolitan background and the bulk of readers ready to read the hidden dark secrets, increase the chance for work of such grotesque nature to prosper.

As in the past the Fabula, jouglers, and minstrels ridicule to gain the attention of the masses, in the same manner, Iranian Nights ridicule a certain group that makes huge laughter in the international readership. As far as the idea of freedom of speech is concerned, Iranian Nights is often seen to be an effort from Ali and Brenton to promote the idea of independence in writing. Salman Rushdie Satanic verses are a part of freedom of speech in the postcolonial exotic context as in the same manner the grotesque and caricatures are justified. The freedom of speech is a fundamental tool in literature, but a onesided stance will always lead to ambiguity as:

"Iranian Nights"--a thinly disguised theatrical defense of Salman Rushdie author of "The Satanic Verses." It turned out to be pretty much an evening for the already converted, the simply curious, and the eager media. (New Theatre Writer,1989, April 21)

As far as the treatment of the subject and characterization is concerned, the play also seems to be only aiming at ridiculing or mocking rather than serving a grand purpose. Written in five days at the backstage of the Royal Court Theatre, the writers might be thinking of entertaining the audiences only. The media hype created because of the controversial topic is itself an example of a grotesque situation. The audiences get what they want at the end of the evening, a Muslim terrorist son, a hybrid Muslim father, a nonsense mullah, and a seductive Sheherazade. In the history of the grotesque art and caricatures, the writers use to travel on streets, and plays were performed and arranged in a little time as per the requirement of the orders placed by the aristocrats. Ali and Brenton were much similar in their mannerism, however, their decision to act in such a manner is intentional or not is still under question. The writers certainly possess a talent if they aim at making grotesque caricature and imitating the same dramaturgy in their play Iranian Nights.

In his article "The Grotesque and Postcolonialism in Shame" Josh Newell (1991) describes that Salam Rushdie uses a fantastic grotesque. According to Nowell, the writer has made monsters express emotions. His treatment of grotesque is best explained as:

Often coined the "satiric" grotesque, these writers reach the grotesque by way of satiric, caricatural, and cynical distortions. Unlike pure satire, however, which aims to separate laughter and anger in our reaction to a scene and unlike caricature, 
which distorts to produce a ridiculous or amusing reaction, the(his) grotesque aims to produce a confusing tragicomic reaction to one particular scene. (Newell,1991)

Newell's perspective on the treatment of grotesque culture is important to the study of grotesque caricatures in Iranian Nights. Ali and Brenton used a similar "fantastic grotesque" by creating caricature which does not only ridicule a certain group but creates a confusing tragicomic reaction in the readers. The caricatures which are exaggerated and distorted images still give a confusing and ambiguous image to the viewers which will ultimately build a stereotypical perception about the third world others.

As a play, it gained a lot of attention from reporters and journalists in London. Ali and Brenton both belonging to the world of journalism themselves were aware of the pros of cons of a controversial play. They utilized the hype in a great manner and were able enough to quote themselves in the books of postcolonial literature. Their work Iranian Nights sets a perfect strategy for a clever successful business as well as unique art of grotesque caricature culture.

\section{Methodology}

A qualitative approach is used for data collection. Moreover, since the body of criticism on Iranian nights as a post-colonial text has been done, the aim is to pinpoint an idea that may seem similar to the previous researches done but unique in terms of grotesque caricature in both dramaturgy and characterization. Grotesque Caricature is a concept related to the distorted and exaggerated images of the character's appearance, feeling, and morals therefore the study will adopt an investigative stance to analyze how and why Ali and Brenton follow the technique of Grotesque caricatures in their play. The goals of the research are thus exploratory and descriptive. The Collection of data will demand to utilize Ali and Brenton's Play Iranian Nights. Other primary sources such as Ali and Brenton's editorials, prefaces, criticism, and interviews will be collected for any insights which might prove useful in explaining the grotesque caricature in their work. Secondary sources, comprising of national/international and critical articles about the play, will also be analyzed and integrated into the discussion.

In chapter one, the art of characterization will be discussed in detail. A comparison will be drawn between the three main characters i.e. Omar, Sheherazade, and Caliph. Not just the major character but the minor characters will also be discussed in detail. The aim is to see the grotesque caricatures drawn out of these characters which will ultimately lead to the main theme of the Exoticism of Orientals.

In chapter two, the dramaturgy and technique will be discussed. The Mimus and fabliaux will be kept at the back of the mind while discussing similarity and difference with the play Iranian Nights. The transformation of characters, storytelling, recitation, and internal monologues as well as animal technique will be highlighted.

\section{Results and Discussion}

Iranian Nights, a play by Ali and Brenton depicts a very stereotypical perception of the third world Muslim others. The attributions which are associated with the third world Muslims are that of sexually perverted and wealthy men and seductive mysterious women. The pinprick which Brenton mentions in his note in Iranian Nights serves the purpose of the research. With the idea of a grotesque depiction of Muslims in mind, the pinprick seems to be an ironic statement that will ultimately generate laughter in the audience. The pinprick is defined as a small puncture but in this play, the freedom of speech is much more than just a prick. Freedom of speech is a matter which is well appreciated in all the cultures and societies including the third world Muslim ones but when the freedom of expression becomes a grotesque caricature to manipulate audiences into an exotic margin then things become problematic.

In the history of literature, the descriptive caricatures and grotesque depiction have always been used to explain reality exaggeratedly. The grotesque caricatures aimed at entertaining people at some time and then the troops headed towards the next party for performance. In the modern age, the reality is exaggerated to ridicule and reform the masses but if the reformation is a one-side story then in post-colonial subaltern and oriental terms the writers are putting others on the margins.

In the art of Characterization, almost all the characters seem to fit in the literary grotesque caricature sphere. The three main characters Caliph, Omar, and Shahrazad are distorted exaggerated characters that shape the basis of the play. Ali and Brenton aim at presenting the ugly and repulsive figure from the Muslim. No heroic attributions are associated with none of 
the characters. They present a very abrupt, horrifying, and ugly outlook of a Muslim durbar, where people come to seek guidance ironically. Their gestures, ideas, and movement almost make them clownish or cartoonish.

The character of a Caliph represents a Rightist Orthodox fanatic, who has built his perceptions about God and religion and doesn't want to be questioned by it at all. His very first word seems to be that of a non-intellectual, rude, and rubbish persona that is a mock to his actual status. The Caliph states " Dog Hast Thou forgotten thine own calendar" (Ali and Brenton,1989, p.1). In these lines, a very slapstick effect is generated introducing the audiences with a cartoonish figure ready to use vulgar language. Later, the Caliph is seen drinking wine and slobbering giving an ugly distorted image of the scholars of Islam. The Caliph in the very beginning shatters any sort of moral information and is like an exaggerated distorted image. He reminds us of a clown who has no intellect at all and enjoy vulgar discussions as " No more morals. Too many mullahs, too many morals. Tell me about wine"(Ali and Brenton,1989, p 2). The writers aim at presenting a very opposing and well-caricatured figure from the beginning to make a confusing tragicomic effect. As a subject topic, Ali and Brenton use sexual discussion which continues for a great deal in the play. The Caliph asks "What about Copulation then? (Ali and Brenton,2). The Caliph is portrayed as a person who can be easily slipped by intimate talks therefore, he says "Arouse me not, it is not my convenience." (Ali and Brenton,1989, p,3)

Scheherazade, the mystery woman of the Arab is also portrayed as a seductive woman. The caricature of Shahrazad is well set up in the minds beforehand when Omar talks about adultery of a wife with a slave. A descriptive grotesque caricature is already given to the audience as "Omar makes a throat-cutting sign" (Ali and Brenton,1989, p. 2) before Scherezade makes an appearance on the stage. Her very first act is to wipe the Caliph's face to show her closeness to him. Omar says, " Scheherazade tells stories which sends a pringle down your dingle" (Ali and Brenton,1989, p. 2) is also one example of grotesque caricature were the characters traits are an exaggeration. Scheherazade a famous seductive figure in history is even more sexually exaggerated to build an exotic image of the Orientals. In comparison with the buffoonish character of the Caliph who talks about sexual intercourse in an abrupt manner, Scheherazade also talks about physical pleasures and body but in a forbidden manner, forcing the readers to want it more as " How can be we talk about wine when the body is so explicit on the subject? It is forbidden, my Lord" (Ali and Brenton, p. 2). Later she straightforwardly enlightens the audiences with copulation as "Copulation is the act which unities the sexes of man and woman..." (Ali and Brenton, 1989, p 3). The intricate details of sexual intercourse and the feeling associated with it, make the readers feel disgusted but then again Ali and Brenton were intentionally creating a grotesque caricature out of Shahrezade as well.

Omar Kayyam, is the character with whom the play starts. Ali and Brenton have presented Omar as a commentator. The commentator of the play in the very beginning talks about a heretic who was shot before he could even make a statement. A hyper-dramatic prologue is thus given at the beginning of the play upon which the whole play will eventually lie. The stereotypical Mullahs and their unjust treatment of the freedom of speech are introduced by Omar in the very beginning again gives a distorted and well-exaggerated picture of Islam. Ali and Breton followed what Edward Said declares "appropriateness". Their definition of Mullah is of one type and therefore their notion must be perfect to all the mullahs of the world. With a very true and grave issue like freedom of speech, Ali and Brenton talk about giving a chance to listen and understand the scholars rather than acting exaggeratedly by killing them ruthlessly. Ironically, the writers did the same with their treatment of Islamic history as they exaggerated the whole picture to make it look more exotic. The clash here lies is that of an orient/oxidant where the binaries are vividly seen confusing the readers in a fantastic grotesque situation. Omar is fighting with dates and the Caliph is correcting him all the time making the readers believe that when the commentators are not aware of the actual history. Omar is seen to be a foil to the other two characters as he doesn't share his own opinion but is just mechanically responding to commands " Highly, my lord ...What about this my lord" (Ali and Brenton,1989, p 2-3). By using Omar as a commentator Ali and Brenton may aim at presenting the masses of the oriental third world other Muslims who do not question the reality of the matter and prefer to be spoon-fed all the time. But then again Omar is another caricature is just a grotesque generalization of a massive population of the oriental.

In grotesque and caricature, the art of characterization is important to understand the complete intention of the author's work. Without the story of all the characters, the understanding of the main theme is not possible. In the history of English Caricature literature, there is an important figure George Cruikshank, a political caricaturist who believed in "Filling a picture with an immense number of figures, everyone telling a part of the story, without which, however minute, the whole picture would seem to us incomplete". (Ali and Brenton,1989 p.178) 
Therefore, to understand the plot, the so-called minor characters must be understood completely as well. The Holy man as depicted by the writer presented as a person who is not able to make any decision but relays on God for all the answers even if injustice prevails as "I cannot do anything for you. I am a simple human being; all is in God's hand now" (Ali and Brenton,1989, p 5) later after his discussion with the intellectual poet he states abruptly. "You will die it is God's will" (Ali and Brenton,1989, p.6). The Poet on the other hand seems to be the only sane character in the whole play who mocks and ridicules the Holy man in a very casual manner. His rational questioning and silence from Holy man again make him a grotesque caricature who is mocked by a real character of flesh and blood.

In the Father/ Son story both the oriental characters are grotesque caricatures in their way. The father is a hybrid Muslim as he goes to mosques but takes wine as well. He has spent his life like an English chap and wishes to die as a pure Muslim. The Son on the other hand is a case of social abuse who has transformed into a monster killing people and making deals with the devil. Ali and Brenton in this story present two extremes of Muslim third world Orientals who have wavered from the right path. The writers have been able to generate what Nowell declared "Fantastic Grotesque" which creates a tragicomic effect creating an ambiguous exotic image of the third world Muslim others.

During the play, the only rational and skeptical dialogues were uttered by the poet, so the main theme tracked by the authors' work is the irrationality of the third world Orientals. From the beginning, a poet is shown dead because he questions religion. Lack of Freedom of Speech and lack of tolerance in the Muslim world then becomes the spotlight of the play.

As far as the matter of dramaturgy and technique is concerned, Ali and Brenton have selected the theatre of Greeks i.e. jogulers and Fabilaux as well as minstrels. In Roman Mimus theatre, the characters use to sing songs and recite the same stories as well as shared scandalous anecdotes. This tradition went on to the French in their theater where the songs were used to recite situations and discussed evils of the society and elite boredom. The same application of songs and recitations can be seen in Iranian Nights where almost all the three main characters sing of a song. The songs are either commentary on the slapstick situations or internal monologues of the characters themselves. At the very beginning of the play, Omar sings of lust which is relevant to the copulation scene. He sings "Lust is not content with blushes/Kisses taken from pure lips/Lust must have a thing which dances/Lust must have a thing which gushes". (Ali and Brenton,1989, p.3)

The song of the Caliph also depicts the inner feeling of a third world Muslim but in a hyperbolic dramatized manner. A certain negative image and dark jealous character is caricatured who is as ugly as his inner self. As he says:

I weary of holy purity/ In a land of Third world Poverty-

I'll go to the west and be free...An Eastern in the West-

I'll sweat, I'll save, I'll do my best

As Americans say, suck it and see (p.11)

The song of Scherezade sings of the reality of the brutality of human nature. Ali and Brenton, with this song, present an overall drastic situation of the world where there is less tolerance and more of war. Viewing this from Edward Said's point of view may be the writers aim at a contrapuntal thought to make the world worth living. But contrapuntal for Scherezade is a miracle too good to be real "To be Superhumanly strong? /More tolerant, more wise/Than any human being/ Can be? The miracle" (Ali and Brenton,1989, p. 19)

The lament of the Father is also a depiction of the hopeless future of the third world Muslims "Fascism in the brown skins that the decent cannot deal" (Ali and Brenton,1989, p.18). He is a grotesque caricature of utter hopelessness as he says "I feel alone", the character of the father presents a man who can see and understand the freedom of speech in a global world and is therefore abandoned by his Muslim community in New York.

The recitations of stories are also one treat of the grotesque and caricature. The characters use to recite stories about important figures in a witty manner and Fabula also consisted of stories and songs to delight the audience. The scandalous anecdotes can be seen in the very beginning of the play depicting an exotic image of the oriental east as "He found his wife in bed with a slave. Chopped her head off" (Ali and Brenton, 1989, p 2). Another similar story is recited by Shehrezade where she talks about a great sultan going to his chambers to stretch and found a stain on his bed. " Can it possibly be fornication, my lord? (Ali and Brenton,1989, p 10). The story highlights the unfaithful oriental females and sexually perverted kings as well as disloyal slaves who aim at saving their lives only. The Tale of the father and the son also offer a moral decay in third- 
world Muslims resulting in activities like drug smuggling and terrorism. The Son is shown as talking to Satan itself on the phone giving a grotesque image of the Orientals. The lines "Only alcohol is forbidden "(Ali and Brenton, p. 17) highlight a hypocrite oriental who aims at being orthodox and destructive for humankind. The story of the Poet and the Holy man also presents a very exotic one-sided picture. The Holy man says " "Every religion that has traveled the west was tainted, dissipated into Satanic mire of self-indulgence". In response to the harsh and orthodox words of the Holy man, the poet is calm and relaxed and is ready to get beheaded if the Holy man can answer his questions. "Look, do you mind if I smoke" (Ali and Brenton,1989, p 6) depicts the poet as a character of intellect and the holy man on the other hand seems to be a grotesque caricature who is mocked not just by the poet but the audience as well. By using the technique of storytelling, Ali and Brenton create caricatures because imagination can give room for absurdity to be justified.

Another dramatic device used by the writer is the shifting of roles in the play. The three main characters in the play shift their roles and transform into something new in a little time. The play seems to be a play within a play. The characters have no sense of identity. There is a continuous shift from one character to the other give them an artificial touch. Like caricatures and cartoons, they can be transformed and sketched all over again e.g. the transformation of Omar into the poet and then the son, the transformation of Caliph into the holy man, and then the father. No transformation has taken place in the female character; therefore, it depicts that like the Greeks the female figure is not given much importance. This also presented an exotic image of the Orientals who oppress women and use them for sexual gratification only.

As for the Mimus and Fabula artist, Tamed animals were also used to act some part of the tales. The characters were somewhat associated with those animals and in generals, those animals share some part of the character's inner reality. The animals were also used to great a comical situation or to create confusion in the plays to generate laughter. In Iranian Nights, the same dramatic technique is used when Shehrezade is seen with a penguin on the stage "Execute that Penguin/Schehrezade pricks the penguin with a large stiletto. (Ali and Brenton,1989, p .5)

To summarize, the dramatic techniques used in the play also highlight the traits of caricature and the grotesque. Using the ideals of slapstick and witty comical caricatures from the Greek work had certainly some importance for Ali and Brenton. By using the techniques of storytelling, animals, the transformation of characters the writers have generated big laughter for those who aim at viewing an exotic image of the third world Muslim oriental with delight.

\section{Conclusion}

To conclude, after a great deal of research on geopolitics and postcolonial literature, Ali and Brenton's Iranian Nights have come to its complete understanding. The paper aimed to present a well-known art of grotesque caricatures used in Iranian Nights. The characterization and dramaturgy have been taken from the Greek word of Mimus which comically portrays lesser human beings. As far as the idea of Exoticism is concerned, Ali and Breton have put the others on the margin to market their idea with a bang. In recent years, most of the research on Iranian Nights have been a view from a one thinly veiled agenda and international politics against Islam.

The third world Muslim others are suffering from the appropriateness of the West. The stereotypical notions are very much the reason for creating a grotesque caricature of Muslim characters that will generate a good deal of laughter in the international readership. Ali and Brenton as advocates of freedom of speech portrayed freedom on one side only. They placed the oriental again on the margins to justify the actions of western scholars.

To take sides or to accuse the writing to set propaganda is not merely the topic of the research. The paper aims at a bigger picture which is the exaggeration of oriental characters for generating exoticism to attract the international market. To say that the play is entirely a thinly veiled agenda may seem an understatement. There are instances where the writers are talking about mutual understanding and a contrapuntal thought. Still, the last segment of the play holds a little worth because the previous section has presented a distorted ugly side of the third world Muslim Orientals. 


\section{References}

[1] Ali, T \& Howart. B (1989). Iranian Nights. Nick Hern Books. Ashcroft.Bill et al (2000) Post-Colonial Studies: The Key Concepts. Routledge.

[2] Brantlinger, P. (2009). Victorian literature and postcolonial studies. Edinburgh University Press.

[3] Dirlik, A. (1997). The Postcolonial Aura: Third World criticism in the age of global capitalism. Cultural Politics, 11, $501-528$.

[4] Huggan, G. (2014). The postcolonial exotic: Marketing the margins. Routledge.

[5] Hawley, J. C., \& Nelson, E. S. (Eds.). (2001). Encyclopedia of postcolonial studies. Greenwood Publishing Group.

[6] Podis, L. A., \& Saaka, Y. (Eds.). (1998). Challenging hierarchies: Issues and themes in colonial and postcolonial African literature (Vol. 5). Peter Lang Pub Incorporated.

[7] Mohanram, R., \& Rajan, G. (1996). English Postcoloniality: Literatures from Around the World (No. 66). Greenwood Press.

[8] Newell, J . (2013). The Grotesque and Post-Colonialism in Shame. The Postcolonial Web

[9] Patke, R. S. (2013). Modernist literature and postcolonial studies. Edinburgh University Press.

[10] Rajan, G., \& Mohanram, R. (Eds.). (1995). Postcolonial Discourse and Changing Cultural Contexts: Theory and Criticism (No. 64). Greenwood Publishing Group.

[11] Tariq. A (interview) by Sashi Kumar (2013). The New World Disorder ". Frontline India, New Dehli.

[12] Wright, T. (2000). A History of Caricature and Grotesque. Project Gutenberg. 